\title{
Style Cypriot Juglets Recently Discovered in Egypt.
}

\section{Dr. Wafaa Emad Abd AL-Fattah Ibrahim}

Style Cypriot Juglets ware small, narrow - necked found at Ras Shamra, northern Palestine at Tel $\operatorname{kabri}\left({ }^{1}\right)$, Jordon $\left({ }^{2}\right)$, Lebanon $\left({ }^{3}\right),\left({ }^{4}\right)$,Tell el- Yahudiyeh , Tell - el Daba, kahun, Memphian, maskhuta, Tell el Sahaba, Bubastis, Inshas, Ghita, Tell El- Koc *in Egypt, Crete, Aegean, Anatolia and Cyprus.

These juglets imported by Egypt, for their usefulness, function, value which clearly designed to be used containers liquids $\left({ }^{5}\right),\left({ }^{6}\right)$,Perfumes, wines, oils olives and fats were employed in ancient Egypt for eating, cooking, illumination for both the living and the dead; libations as a base for medicines and doubtless for many other purposes $\left(^{7}\right)$.

Merrillees, believe that this Cypriote juglets imported to Egypt, for their ornamental and asset and their intrinsic or contents $\left({ }^{8}\right)$

- The Ministry of Antiquities

${ }^{1}$ Bergoffen.C, The Cypriot Bronze Age pottery from sir Leonard Wolleys Excavation at Alalakh (Tell Atchana),cchem5,Vienna.2005, p.47,48.,

${ }^{2}$ Merrilles,R.S ,The Absolute chronology of The Bronze age in Cyprus, RDAC,1977, P.33-50.

${ }^{3}$ Kempinski, A, Tel-kabri,the1986-1993Excavat- tion Seasons, Tel Aviv.,2002,fig.5.20.

${ }^{4}$ Charaf, H. The Bronze Age, Cypriote pottery from Tell -CARQA in north Lebanon, CAARI news, No. 23 ,24 ,8-9, N.Y.,2002.

${ }^{*}$ Tell El- koc: about $50 \mathrm{~km}$ west of Ismailia City, $100 \mathrm{~km}$ east Cairo.

5 Maguire, L.C, the circulation of Cypriot pottery in the middle bronze age , Edinburgh , 1990, P.78.

6 Bietak ,M. , Tall El- Dabca II der fundort im Rahman einer archaologisch geographichen untersuchung uber das agyptische ostdelta.UZKI, Vienna .s.165.

7 Belgiorno, M.R. Pyrgosmanroraki, Advanced Technology in Bronze Age Cyprus department of antiquities Cyprus Nicosia,2004.

${ }^{8}$ Knpp,A.B., Prehistoric and proto historic Cyprus insularity,

Connectivity ,Oxford,2008,P.132 
the Cypriot juglets continued to find its way into Egypt, despite the transformation of its external appearance because its remained desirable, $\left({ }^{9}\right)$ I was believe that cultural between east and west in Egypt related to different pattern of commercial with Levant .

in this connection a direct correlation has been established between the patter of Cypriot juglets in this island, Syria, Palestine \& Egypt $\left({ }^{10}\right)$.

The early Cypriot connection represents potters living in Delta using hand, representative of Cypriot pottery, juglets and some jars etc. $\left({ }^{11}\right)$.

In the MBIIA period juglets are very common the throughout Palestine, Syria and Jordon as well as eastern Nile Delta by exchange. In Tell EL-Dabca there are examples imitations of Cypriot juglets, the fabrics from Nile clays similar to those used for Tell el-Yahudiyeh. there was contact because objects of Cyprus are found at Levant and Egypt by tread $\left({ }^{12}\right)$.

The juglet in figure 1 , we noticed that the short cylindrical neck (similar of fig 13$)\left({ }^{13}\right)$.

handle from rim to shoulder like most figures which were found at Tall El-koc the decoration with linear patterns of horizontal

\footnotetext{
${ }^{9}$ Merrillees ,R.S., the early history of late Cypriot 1, on opium, pots, People and places, Sweden, 2003 .P.47.

${ }^{10}$ Astrom, P.,the Swedish Cyprus expedition, vol.IV 1B ,

Swedish.1972,P.208.

${ }^{11}$ Seton - Williams , V., A painted Pottery of the second Millennium From southern turkey and northern Syria ,Iraq 15,1953,56,P.56 -68.

${ }^{12}$ Maguire, L.C, Tell El-Dabca XX1, the Cypriot Pottery and its Circulation in the levant, Wien ,2009,P.38.

${ }^{13}$ Van Setrs,F.the Hyksos , Anew Investion ,New Haven, 1966,P.20-26.
} 
Figure 1 the juglets in figure1, we noticed that the short cylindrical neck handle from rim to shoulder like most figures which were found at Tall El- koc, the decoration with linear patterns or horizontal parallel lines around neck and body, also like many juglets in Cypriot style in Tall El- koc, The body of this juglet is always richly decorated with symmetrically arranged linear motifs and this shape is typical of

Northern part of Cyprus, which was exported widely all over the island $\left({ }^{14}\right)\left({ }^{15}\right)\left({ }^{16}\right)$.

The decoration in figure 2 Cypriote white painted line style, this style found its way to the Nile valley like my juglet, have a flat base, its body similar of Cy priote juglets (fig 5) $\left({ }^{17}\right.$ ).

Another comparable juglet was found by Schaeffer at Ras Shamra in Ugarit, also (fig.XXX1115) similar of base.

Figure 3 another Cypriot white painted line style (fig. 13) but with a different base and decoration, $\left({ }^{18}\right)\left({ }^{19}\right)\left({ }^{20}\right)$.

It was found insied tomb erected with mud bricks its upper body, cylindrical neck, the handle from rim to shoulder similar of (fig 13.14 it's similar in neck handle of Cyprus juglet

The body decorated with two ways lines every one flanked with two parallel straight lines in a horizontal motifs like which was found in south eastern wares from Cyprus.

\footnotetext{
${ }^{14}$ Karageorghis V.,Cypriot antiquities in the phylactou collection,Nicosia,2010,p.28.Fig .13. Nicosia,2010,p.28. Fig .13.

${ }^{15}$ Salter ,S., A Catalogue of Cypriot antiquities Cyprus , 2008, P33,Fig,. 14.

${ }^{16}$ Astrom ,P., corpus of Cypriot antiquities, vol. XX- XX11, Sweden,2004, PL.4.2.

${ }^{17}$ Daver,W.G,new vistas on the MB1 Horizon in Syria-Palestine,Basor237.1980, P.50,Fig.5

${ }^{18}$ Hennessy, J.B. Studies in - Mediterranean archaeology Vol.1XXX11,Goteborg , 1988, Fig .20,8.

${ }_{19}$ Astrom ,P., the Swedish corpus expedition, vol.IV 1B, Swedish ,1972, Fig.XXX11

${ }^{20}$ Van Setrs,F.the Hyksos , Anew Investion ,New Haven, 1966,P.20-26.
} 
Figure 4 The cylindrical neck, handle from rim to shoulder, upper body similar of the juglets which were found in kalopsidha and Enkomi so similar to Tell El-Dabca $\left({ }^{21}\right),\left({ }^{22}\right)\left({ }^{23}\right)$.

Figure 5 the handle, nick, and global body similar in decoration of Cypriot juglet (fig.xxv10). $\left({ }^{24}\right),\left({ }^{25}\right)\left({ }^{26}\right)$.

Figure 6 Bichrome Spouted juglet, averted rim handle from rim to the shoulder, decorated with fine stripes encircled round base, $\left({ }^{27}\right)\left({ }^{28}\right)\left({ }^{29}\right)$.

I believe that there is no specimens in Cyprus typical of which we

Found in Tell EL-Koc, I see it after my worked on the region of Tall Al-Koc and witnessed its discovery stages also became aware of every part of this site.so visited Nicosia and Cypriot Museum, and met with professors in Cypriot Institute and University.

${ }^{21}$ Karageorghis, V., Cypriot antiquities in the phylactou collection,

Nicosia,2010,p.33. Fig .13,14.

${ }^{22}$ Astrom ,P., corpus of Cypriot Vasorum antiquities, Sweden 1985, Fig .16.P.14.

${ }^{23}$ Astrom ,P., corpus of Cypriot antiquities, vol. XX13, Sweden ,2004,Fig 23.6,7.

${ }^{24}$ Maguire, L.C, Tell El-Dabca XX1, the Cypriot Pottery and its Circulation in the levant, Wien ,2009,P.38,39.

${ }^{25}$ Salter ,S., A Catalogue of Cypriot antiquities Cyprus , 2008, P33.34,Fig,. 14.

${ }^{26}$ Maguire, L.C, Tell El-Dabca XX1, the Cypriot Pottery and its

Circulation in the levant, Wien ,2009,P.27.

${ }^{27}$ Astrom, P.,the Swedish Cyprus expedition, vol.IV 1B , Swedish.1972,P.208Fig XXV.10.

${ }^{28}$ Hennessy, J.B. Studies in - Mediterranean archaeology Vol LXXX11, Goteborg , 1988, Fig .27,3,9.

${ }^{29}$ Salter ,S.,A Catalogue of Cypriot antiquities university of Melbourne, 2009, P28.38. 


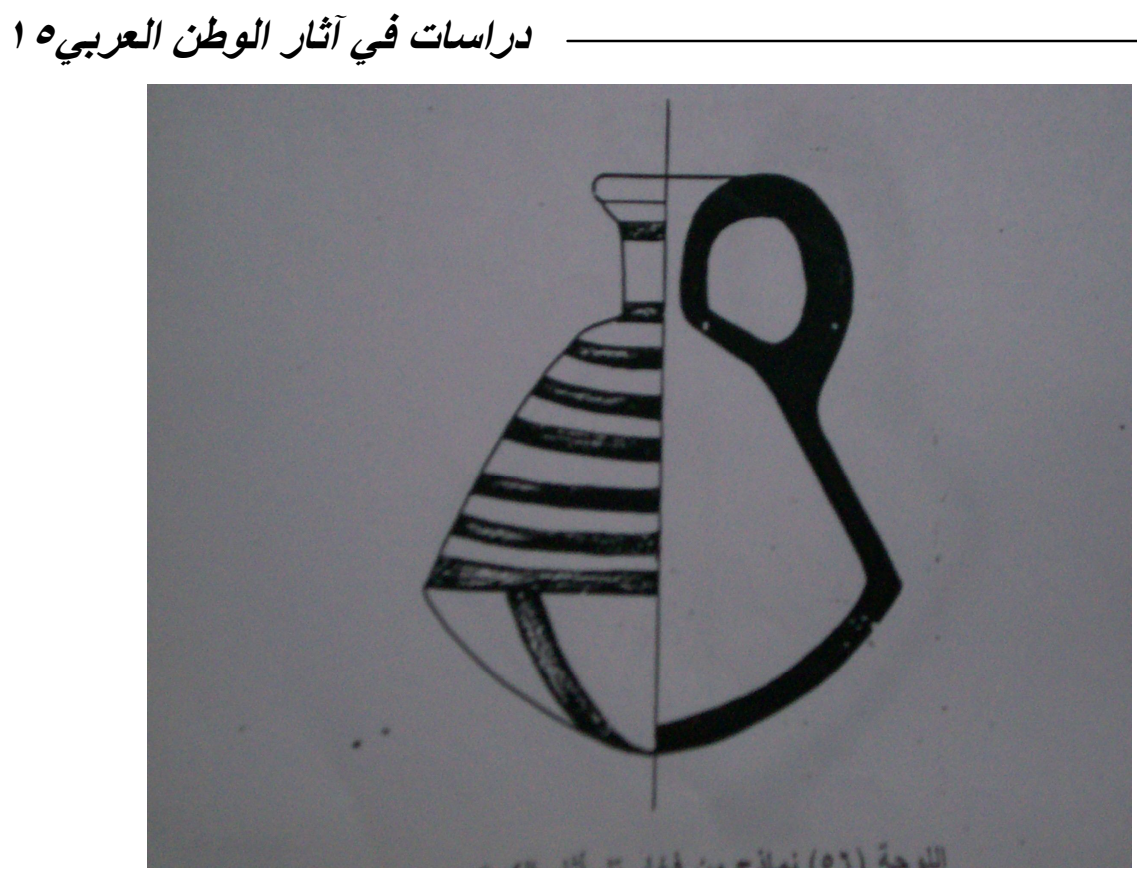

Fig (1)

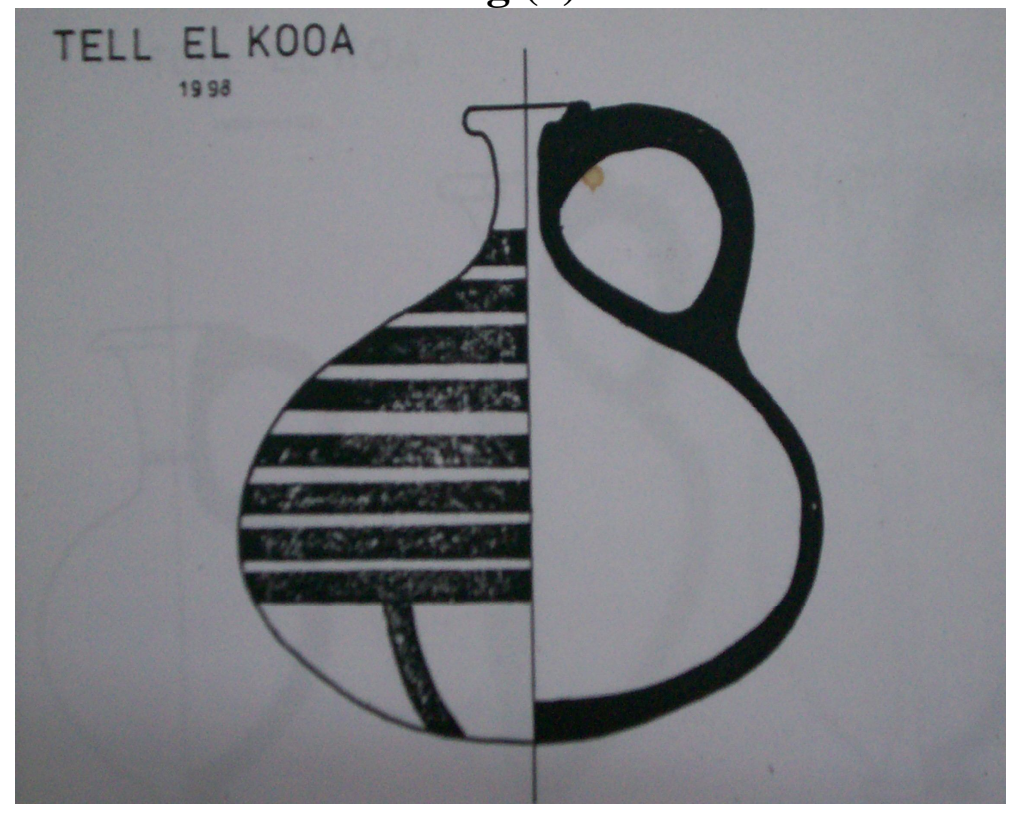

Fig (2)

- 275 - 


$$
\text { دراسات في آثار الوطن العربيه } 1
$$

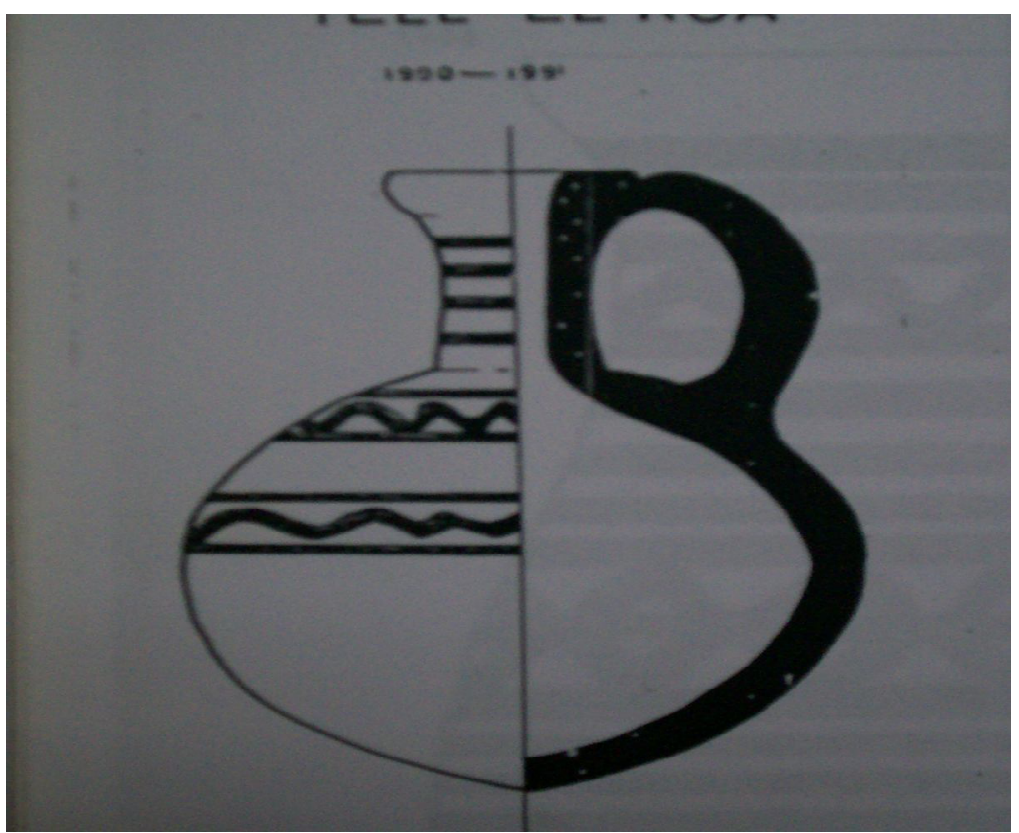

Fig (3)

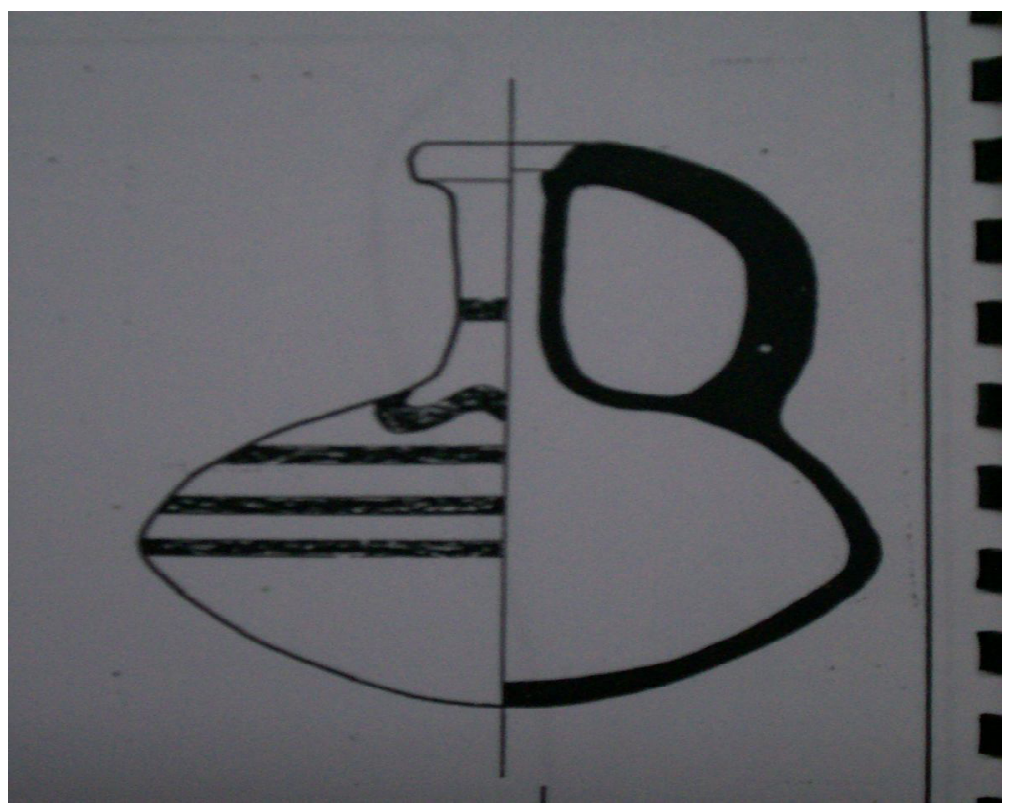

Fig (4)

- 276 - 


$$
\text { دراسات في آثار الوطن العربيه } 1
$$

Fig (5)

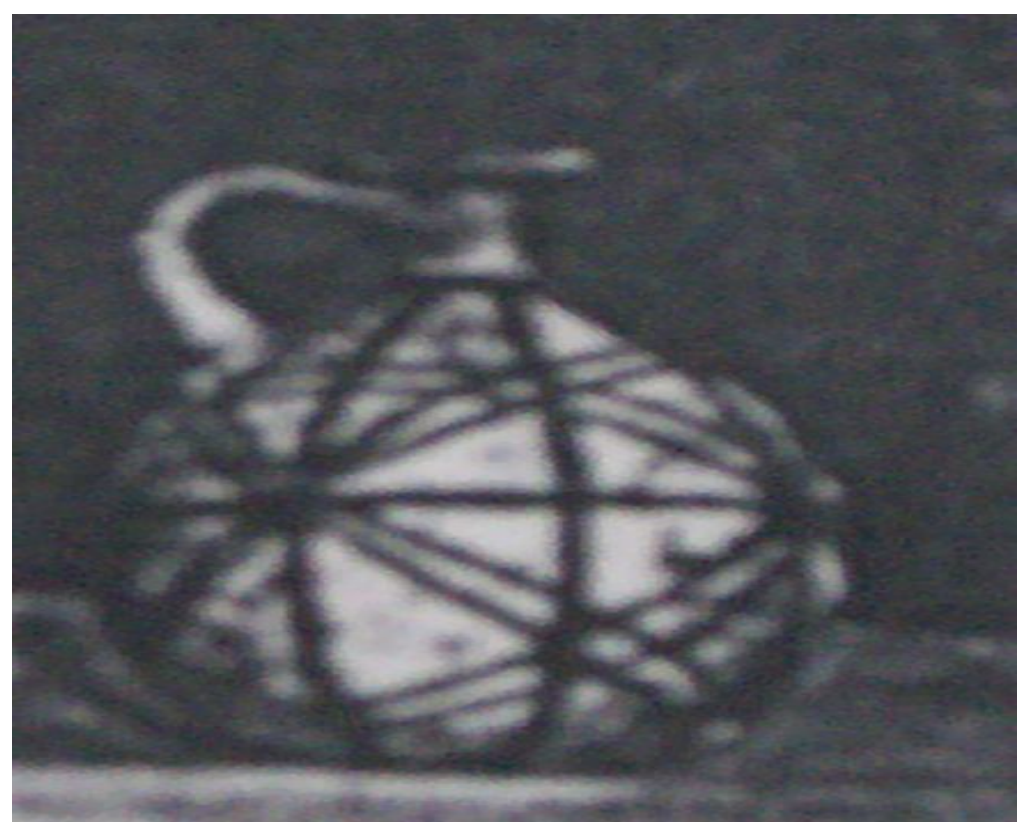

Fig (6)

- 277 - 